\title{
Smart textiles perspective for the Romanian fashion industry
}

\author{
DOI: 10.35530/IT.071.06.202018
}

\section{ABSTRACT - REZUMAT}

\section{Smart textiles perspective for the Romanian fashion industry}

Fashion companies started to use advanced technologies for their new collections to grow their business. Smart textiles add value and differentiate products on the market. The application possibilities of smart textiles are often limited only by our creativity and imagination. But for the most part, modern wearables represent a narrow niche market. We interviewed twelve managers from different Romanian fashion brands. This research paper aims to show which is the opinion of Romanian fashion managers about smart textiles and if they have experience within this field. This study sets the ground for future marketing research regarding the potential demand for smart clothing in Romania.

Keywords: advanced garments, fashion industry, smart clothing, smart textile, wearable

\section{Perspectiva textilelor inteligente pentru industria modei din România}

Companiile din domeniul modei au început să utilizeze tehnologii avansate pentru noile lor colecții, pentru a-și extinde afacerea. Textilele inteligente adaugă valoare și diferențiază produsele pe piață. Posibilitățile aplicării textilelor inteligente sunt limitate doar de creativitatea și imaginația noastră. Dar în cea mai mare parte, tehnologiile "purtabile" moderne reprezintă o nișă de piață redusă. Au fost intervievați doisprezece manageri de la diferite branduri de modă românești. Această cercetare dorește să prezinte opinia managerilor din domeniul modei privind textilele inteligente și experiența în acest domeniu. Studiul nostru pune bazele pentru cercetări viitoare privind cererea potențială pentru produsele de îmbrăcăminte inteligente în România.

Cuvinte cheie: produse avansate, industria modei, îmbrăcăminte inteligentă, textile inteligente, tehnologii "purtabile"

\section{INTRODUCTION}

Smart textiles could sense different stimuli from the environment, reacting and adapting to them by integration of functionalities in the textile structure [1]. Smart garments are able to sense different stimuli such as mechanical, thermal, optical, chemical, electrical or magnetic stimuli, to respond and adapt to them [2]. Smart textiles could be also known as intelligent textiles, stimuli-sensitive or environmentally responsive [1] or e-textiles. Advanced garments such as fire-resistant, waterproof or breathing garments are not considered smart textiles.

Since the beginning of the $19^{\text {th }}$ century fashion designers started to introduce electricity in their new clothing collection, developing a series of illuminated items, such as hats or costumes [3]. Since then, the fashion designers developed new smart concepts using different technologies, generating an enormous potential to this field. The development of smart textiles has the potential to revolutionize the aesthetics and functionality of our clothing. Nanotechnologies application results in new functionalities such as sensing, self-cleaning, communicating, lighting or shape memory.
The intelligent textiles can be classified into three subgroups:

- Passive smart textiles are the first generation of smart textiles and they can only sense the environmental conditions. Examples are textile changing colour, shape, thermal or with electrical resistivity.

- Active smart textiles are the second generation of smart textiles; they can sense and react to the environmental stimuli. They also have an actuator function. Examples of active smart textiles could be shape-memory, chameleonic, water-resistant, heat-storage or thermo-regulated fabrics [4].

- Ultra-smart textiles represent the fabrics having triple functions - they can sense, react and adapt. They have sensors, which can receive external stimuli, and they can react and adapt/reshape to the environmental conditions. Examples of ultra/ very smart textiles are the space suits, thermo regulating clothing or health monitoring apparel.

The result of smart textiles interest generated the expansion of commercial products and the development of new techniques for incorporating electrical functionality into garments [5]. The terms used to designate this concept of smart textiles have multiples names: "smart textile", "intelligent textiles", "e-textiles", "fibertronics" or "electronic textiles" [6]. 


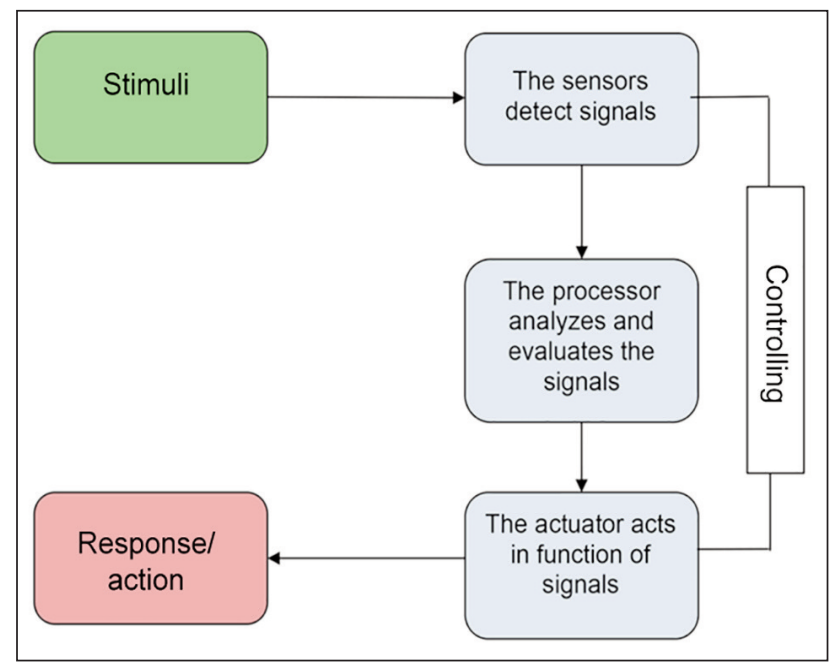

Fig. 1. Smart textile operations

Here are some of smart textile functions in fashion industry:

- Health monitoring system;

- Warning signaling function;

- GPS system;

- Environmental protection;

- Massage or acupuncture function;

- Intelligence temperature control;

- Body posture control;

- Music playing function;

- Light/color change in function of external stimuli;

- Shape changing function;

- Emitting scent function;

- UV protection;

- Compatibility with Phone, iPad control,

- Wireless communication;

- Protection against chemical and biological warfare;

- Waterproof functions.

Every year numerous inventors apply for patents applications in the smart textiles field such as acupuncture therapy using smart thermal textile [9], piece of fabric that has computer-based technology woven into it or adaptive smart textiles that facilitate reduced energy consumption [10].

\section{SMART TEXTILE USE IN ROMANIA}

During the last years we observed an increased interest for smart textiles in Romania. The Faculty of Industrial Design and Business Management from lasi developed a modern research laboratory for smart textiles and fashion design. The National Institute for Research and Development of Textiles and Leather products from Romania is a central promoter of smart textile applications. Siderma Company is a Romanian producer of smart fabrics for different industries, such as fashion, footwear, military, environmental protection, automotive or furniture [11].

Still there are only a few Romanian companies interested in this field. To develop new smart textiles needs a lot of scientific and technical human capital and financial resources.

\section{METHODOLOGY}

In order to understand which is the smart textile perspective for the Romanian fashion industry, we designed a qualitative research with twelve managers who developed national fashion brands in Romania [12]. They include 10 CEOs, one marketing manager and one production manager from 5 large and 7 SME organizations, 6 of them using the lohn system, one working for a luxury brand and 5 for Romanian designer brands. We used semi-structured interview we could get important data about their experiences and opinion. Each interview was forty minutes long, blending closed-ended and openended questions.

International brands use smart textiles to grow their business, revolutionizing the aesthetics and functionality of the clothing. Do the Romanian fashion companies use smart textiles for their new collections? designers [8]. 
How do they implement it in their production lines? How do they promote it?

\section{FINDINGS AND CONCLUSIONS}

The semi-structured interview guide covered four topics:

- What do they know about smart textiles?

- Experiences with smart textiles.

- Difficulties in using smart textiles for their new collections.

- Futures plans to use smart textiles.

\section{What do Romanian fashion managers know} about smart textiles?

All the interviewees heard about smart textiles, but less than $50 \%$ could give us more examples and information about this topic. Light emitting smart textiles and health monitoring textiles for sport clothing are the most popular concepts among them. They don't know any local or international smart textile producer or developer. The Romanian designers heard, for the first time, about smart textiles in faculty and from TV shows.

Usually the Romanian clothing manufacturers heard about smart textiles at international trade fairs and exhibitions (France, Germany). There is a medium degree of interest for smart textiles use. The biggest threats are: there is a low interest from potential clients, and even if they offer a new concept to the market, how do they find smart textiles developers and manufacturers?

\section{Experiences with smart textiles}

Only one interviewee has experiences with smart textiles. This factory from Sighisoara is managed by a young manager very open to challenges and smart textile applications. Her studies in Germany and Australia helped her to approach clients from Western Europe easier, such as Germany, Netherlands or Denmark clients. They developed prototypes and small productions with smart textiles, which needed special production models and patterns. This could be a good beginning for a long-term collaboration between the manufacturer and the client.

Regarding the other managers they didn't receive any requests to use smart textiles from their clients and they don't have experiences within this field. Smart textiles involve additional costs, research and people training - usually the managers from Romanian fashion industry are not willing to assume it.

\section{Difficulties in using smart textiles for their new collections}

The use of smart textiles could be considered a longterm strategy for attracting new clients and retention of the existing clients. We observed that especially managers that are early adopters, with design or economics superior studies, want to use smart textiles for growing their business. They don't expect immediate profit, and they know that innovative projects like that are risky. The use of smart textiles involves extra investments for people's training, production and research.

This qualitative research identifies fourteen challenges that Romanian fashion companies have in using smart textiles. These challenges are structured in four implementation business phases.

There are many uncertainties regarding smart textiles: Where do they find smart textile manufacturers? How do they wash smart textiles? Do the manufacturers have after-sales services? Do the manufacturers sell small quantities of smart textiles? How durable smart textiles are? Is my target market interested in smart textiles?

\section{Futures plans to use smart textiles}

More than half of interviewees said that they would use smart textiles for promotion and entertainment, and not for profitability. The main interest was for changing color smart textiles and light emitting smart textiles. We observed that designers and small producers are more willing to use smart textiles in the future than bigger companies. Managers from bigger fashion companies said that they would use smart textiles only if they see in another place a nice use of smart textiles and if that solution was already tested. They said that Romanian clients are more interested in natural fabrics than in synthetic fabrics requested by smart technical solutions.

There are many uncertainties regarding the smarttextiles developers, the demand, the production costs and functionality. After our interviews, two managers

\begin{tabular}{|c|c|}
\hline \multicolumn{2}{|c|}{ CHALLENGES IN USING SMART TEXTILES } \\
\hline I. Business Vision Statement & II. Concept Development \\
- Immediate profit thinking & - People's training \\
- Easy production implementation & - Research \& development \\
- Decision making process & - Innovative technical solutions \\
& - Creating added-value \\
\hline III. Implementation, trails and errors & IV. Sell \& marketing \\
- Increase in budget production solutions & - Build trust \\
- Increase in budget prototypes stage & - Generate competitive advantage \\
- Long time to market & - Differentiate from other competitors \\
& - Customer analytics \\
\hline
\end{tabular}


contacted us to ask for more information or some smart materials to test.

The biggest question now: Is there demand for smart clothing and accessories? This could be the starting point for a new quantitative research regarding smart clothing and accessories demand in Romania.

\section{ACKNOWLEDGMENT}

This research was financially supported by project CNFISFDI-2018-0582 - Supporting Excellence Research within
The Bucharest University of Economic Studies in the context of the principles of sustainable development and open research. 6. Supporting field research excellence in universities and by project PN-III-P1-1.2-PCCDI-2017-0800 Empirical modeling and experimental development of tools associate with technologies in the field of online social networks - 86PCCDI/2018, Beneficiary: The Bucharest University of Economic Studies.

\section{REFERENCES}

[1] Patnaik, A., Patnaik, S., Fibres to Smart Textiles: Advances in Manufacturing, Technologies, and Applications, CRC Press, 2019, 390

[2] Koncar, V., Smart Textiles for In Situ Monitoring of Composites, Woodhead Publishing, Elsevier Ltd, 422, 2019, https://doi.org/10.1016/C2016-0-04506-0

[3] Syduzzaman, M., Patwary, S.U., Farhana, K., Ahmed S., Smart Textiles and Nano-Technology: A General Overview, In: Textile Science \& Engineering Journal, 2015, 5, 1, https://doi.org/10.4172/2165-8064.1000181

[4] Zhang, X.X., Tao, X.M., Smart textiles (2): Active smart, In: Textile Asia, 2001, 32, 7, 49-52

[5] Tilak, D., Electronic Textiles: Smart Fabrics and Wearable Technology, 1st Edition, Woodhead Publishing, 2015

[6] Paret, D., Pierre, C., Wearables, Smart Textiles \& Smart Apparel 1st Edition, Kindle Edition, Publisher: ISTE Press - Elsevier, 2018

[7] Pentescu, A., Orzan, M., Ştefănescu, C.D., Orzan, O.A.., Modelling Patient Satisfaction in Healthcare, In: Economic Computation and Economic Cybernetics Studies and Research, 2014, 48, 4, 153-166

[8] Deng, H.-Y., Cui, Y.-M., The Application of Smart Textiles in the Brand Fashion Design, In: MATEC Web of Conferences, 2016, 61, 04022

[9] Li, L., Wai-man, A.R., Wong, T.K.S., Li, Y., Chung, J.W.Y., Wan, S.H., Smart thermal textile for acupuncture therapy, US 9603197B2, Application US12/216, 2008, Available at: https://patents.google.com/patent/US9603197B2/en [Accessed May 2020]

[10] Jin, S., Gardner, C., Zhong, Y., Kim, G., Chen, R., Choi, C., Kim, Y., Adaptive smart textiles, method of producing them, and applications thereof, WO 2017/096044 Al, US, 2016, Available at: https://patents.google.com/patent/ W02017096044A1/en [Accessed May 2020]

[11] The Faculty of Industrial Design and Business Management, lasi, Available at: https://dima.tuiasi.ro/ cercetare/laboratoare-de-cercetare-dezvoltare/ [Accessed May 2020]

[12] Ceptureanu, E.G, Ceptureanu, S.I., Orzan, M.C., Bordean, O.N., Rădulescu, V., Empirical Study on Sustainable Opportunities Recognition. A Polyvinyl Chloride (PVC) Joinery Industry Analysis Using Augmented Sustainable Development Process Model, In: Sustainability, 2017, 9, 10, https://doi.org/ 10.3390/su9101779

\section{Authors: \\ CRISTIAN MIHAI ORZAN ${ }^{1}$, IULIA-ADINA ZARA ${ }^{1}$, MARGARETA STELA FLORESCU ${ }^{2}$, OLGUTA ANCA ORZAN ${ }^{3}$}

${ }^{1}$ Bucharest University of Economic Studies, Faculty of Marketing, Bvd. Dacia no. 41, 010374, Bucharest, Romania e-mail: mihai.orzan@ase.ro, iulia.zara@mk.ase.ro

${ }^{2}$ Bucharest University of Economic Studies, Faculty of Public Administration and Management, Piata Romana, no. 6, 010374, Bucharest, Romania

3University of Medicine and Pharmacy "Carol Davila", Bvd. Eroii Sanitari no. 8, 050474, Bucharest, Romania e-mail: orzan@yahoo.com

Corresponding author:

MARGARETA STELA FLORESCU

e-mail: margareta.florescu@ari.ase.ro 